\title{
Curriculum as a System and Influence on Curriculum Renewal at Primary School (SDN) Bareng 03 Malang, Indonesia
}

\author{
Rifda Sofi Illiyin \\ Department of Educational Management \\ Universitas Negeri Malang, Indonesia \\ rifda502@gmail.com
}

\author{
Rizki Fidayati \\ Department of Educational Management \\ Universitas Negeri Malang, Indonesia \\ rizkifidayati2295@gmail.com
}

\author{
Imron Arifin \\ Department of Educational Administration \\ Universitas Negeri Malang, Indonesia \\ imron.arifin.fip@um.ac.id
}

\begin{abstract}
The preparation of this paper aims to understand and analyze curriculum system theory and curriculum renewal at the level of the elementary school education unit and aims to study the discovery of problems related to the curriculum system implemented in the School and be linked to the theory used to later find solutions to problems found. The research method used is a qualitative approach in which this study describes or depicts facts or circumstances or symptoms that appear in SDN Bareng 3 Malang, Indonesia. Research steps undertaken begin with Case Selection, Data Collection, Data Analysis, Corrections, and Report Writing. The results of the study can be found the application of the curriculum system at the basic education level unit. curriculum as a system if every component in the curriculum takes place as a whole. The implementation of curriculum development that applies in schools starts from the main curriculum which is a national curriculum then adjusted to the situation of the school so that it becomes 3 documents, document 1 is the center of all school activities, document 2 is a syllabus and document 3 is lesson plan (RPP). so that it can be said that the implementation of the curriculum system at SDN Bareng 3 Malang adjusts the needs of students in understanding the learning process referring to the development of the use of the 2013 curriculum by including certain parties such as heads of agencies, supervisors, school committees, principals, teachers and student guardians in the needs analysis implementation of the school curriculum system.
\end{abstract}

Keywords: system, curriculum, curriculum renewal, national curriculum, syllabus, lesson plan

\section{INTRODUCTION}

Education is part of learning activities through formal and non-formal institution to educate the nation's life. According to Republic of Indonesia Law about National Education System No.20/ "Education is an effort to create an atmosphere and learning process so that students actively develop their potential in order to have strength spiritual, self-control, personality, noble moral intelligence, and the skills needed by himself, society, nation and state. So that it can be said that education is a real thing that done by students in the process of gaining knowledge and developing their own potential based on prevailing norms. In the implementation of the students make the school as a place to learn, develop themselves, and actively interact to achieve educational goals that are adjusted to established standards, it can be said that the implementation of education into a unified system that are interrelated with one another.

Philip Phenix in Lunenburg (Ryeo, Emzir, \& Kora, 2018)defined the curriculum as what is studied, the "content" or "subject matter" of instruction. Hubball \& Burt (in Rumahlatau, Huliselan, \& Takaria, 2016), states that the reformation of curriculum is a complex, diverse, and repetitious process, in which ideas are made into policies, transformed into behavior, and expressed as social actions. Briggs (Andrian, Kartowagiran, \& Hadi, 2018) state that the curriculum provides guidance and a foundation for schools in developing learning and assessment. Efforts to improve the curriculum in order to achieve successful learning becomes something that absolutely must be done. In curriculum design, a country's educational policies, goals, mission and vision are interpreted and transformed into general objectives, which can be easily transferred by school teachers into instructional objectives and learning standards (Nhlapo \& Muharajh, 2017).

Based on general theory the system is based on laws and concepts to form a foundation in diverse fields. Legal identification and principles can be used to bring knowledge together. So basically, it happens because of cause and effect (Hamalik, 2013). Interdependence between variables in a system is one of the widest inductions of experience that can be considered as a system. Pedler \& Evans (Cooper, 2017) states that an action-learning method was used for the curriculum implementation phase of the project. The action-learning method begins with the assumption that existing programmed knowledge is not always sufficient when faced with real-world problems in context. If related to the position of the curriculum in the national education system according to (Suparlan, 2011) are (Table 1):

Carrying out the education function with the hope of achieving educational goals requires a program that is systematically and logically bred in accordance with student development. (Arifin, 2014) In supporting the implementation of the whole education system several components are needed such as one curriculum, because education and curriculum are interrelated as well as a system that runs interconnected. (Wahyudin, 2014) If the curriculum runs well and is supported by other components, the learning process will run well and produce quality students. 
Table 1

Curriculum Position in the Education System

\begin{tabular}{|c|c|c|}
\hline No & Education Component & Education Subcomponent \\
\hline 1. & Learners (student) & $\begin{array}{l}\text { 1.1 Intellectual intelligence } \\
\text { 1.2 Perseverance } \\
\text { 1.3 School readiness } \\
\text { 1.4 Previous knowledge } \\
\text { 1.5 Learning Obstacles }\end{array}$ \\
\hline 2. & Teaching and Learning & $\begin{array}{l}\text { 2.1 Study Times } \\
\text { 2.2 Teaching Methods } \\
\text { 2.3 Assessment, feedback, intensive or reinforcement } \\
\text { 2.4 Number of students in the class }\end{array}$ \\
\hline 3. & Instrumental input, nabling input & $\begin{array}{l}\text { 3.1 Materials that used in the teaching and learning process } \\
\text { 3.2 Facilities and infrastructure } \\
\text { 3.4 Human Resources } \\
\text { 3.5 School governance }\end{array}$ \\
\hline 4. & Environments or Contexts & $\begin{array}{l}\text { 4.1 Socio-economic market conditions } \\
\text { 4.2 Socio-cultural factors } \\
\text { 4.3 Assistance strategy } \\
\text { 4.4 Educational knowledge and supporting infrastructure } \\
\text { 4.5 Community resources are available for education } \\
\text { 4.6 The competitiveness of the teaching profession within job market } \\
\text { 4.7 The philosophical point of view of the teacherand students } \\
\text { 4.8 Peer influence } \\
\text { 4.9 Parental support } \\
\text { 4.10 Available time for } \\
\text { 4.11 Study at school and home } \\
\text { 4.12 National standard } \\
\text { 4.13 Community expectations } \\
\text { 4.14 Labor market demand } \\
\text { 4.15 Globalization }\end{array}$ \\
\hline 5. & Output and outcomes & $\begin{array}{l}\text { 5.1 Literacy, arithmetic skills, and life skills } \\
\text { 5.2 Creative skills andemotional values } \\
\text { 5.3 Social benefits }\end{array}$ \\
\hline
\end{tabular}

The curriculum has undergone renewal, with the renewal, it means that the existing system of learning also changes. The curriculum renewal is part of the development used by schools to innovate with the aim of the school being able to create superior quality (Abdullah, 2011). This underlies researchers interested in understanding about a curriculum system that is implemented in schools, as the system runs in tandem to carry out the learning process and school activities that create stimulus for students to be more active and participatory in the learning process. For this reason, researchers conducted a field study in one of the top schools in Malang, namely SDN Bareng 03 Malang.

\section{METHOD}

This study uses a qualitative descriptive approach in which this study describes or depicts facts or circumstances or symptoms that appear at the research site in this case at SDN Baron 03. Qualitative descriptive research seeks to describe all the symptoms or conditions that exist, namely the condition of symptoms according to what they are at the time of the study (Mukhtar, 2013).

Qualitative research is aimed at understanding social phenomena from the participant's point of view. Qualitative research is used to examine the condition of natural objects where the researcher is a key instrument (Sugiyono, 2010). The data source referred to in the study is the subject of where the data was obtained. In this study the authors use two data sources, namely: (1) Primary data sources, namely data directly collected by researchers from the first source. As for the primary data source in this study is Mrs. Dina As Waka Curriculum. At SDN Baron 03 Malang City; and (2) Secondary data sources, namely data directly collected by researchers as a support of primary sources. It can also be said that the data is arranged in the form of documents. In this study, secondary data sources obtained such as documentation, curriculum related documents used by the school. Data collection techniques used in this research triangulation is to combine various data collection techniques and data sources. The aim is to test the credibility of the data by checking the credibility of the data with data collection techniques and various data sources, by conducting interviews, observation and documentation

The steps taken in the field approach are as follows: (1) case selection is based on the object of research that will be conducted so adjusted by reviewing theories related to research material about the curriculum system at the level of the elementary school education unit and related to curriculum renewal management; (2) data collection techniques carried out in this study through case studies in the field which use several stages such as interviews, observation and documentation related to the curriculum used at SDN Baron 03 Malang; (3) analysis data conducts analysis of data obtained from schools, adjusted to the study of theory, after being managed based on a theoretical study and the results of case studies in the field then used in report writing; (4) improvements are carried out by adjusting the data found with the results of the documentation obtained. If the data obtained is deemed inadequate then it is necessary to return to the field to be completed and refined; and (5) report writing is done systematically, structurally, with the language used more easily understood by the readers.

\section{RESULT AND DISCUSSION}

As explained above, the curriculum as a system has an explanation that the curriculum is part of several 
components that form a unified whole and between one component influence each other. In the context of curriculum design and development, curriculum developers must pay attention to the basic framework of the curriculum with a system approach, namely curriculum that has key components, both at the macro (national) level, institutions (institutions), fields of study or subjects, as well as at level of learning program (Syllabus, RPP).

From the results of the case studies in the field the curriculum as a system that applies in schools starts from the main curriculum which is a national curriculum then adjusted to the situation of the school so that it becomes 3 documents, document 1 is the center of all school activities, document 2 is a syllabus and document 3 is RPP. The use of curriculum in schools has gone through several stages of revision since 2014, namely since the advent of the 2013 curriculum until the last revision in 2017.

The implementation of the school curriculum system is interrelated to each other in order to run according to the system, for example the Adiwiyata school, in which environmental management is organized, there are other programs such as PPK (Character Education Development), 21st Century skills, and must be integrated into the curriculum. Being a unit that cannot be disaggregated based on activities but must be put together based on the curriculum used in schools. In fact, each vision and mission of the school is based on each of these activities but is still listed thoroughly in the curriculum.

\section{School Curriculum System}

Every school program without exception one of them extracurricular activities also refers to the existence of a curriculum used by the school. So that at the beginning of each new school year every aspect of the school that is responsible for compiling the curriculum that will be used in this case will play a role, namely teachers, principals, supervisors, offices, school committees formulating KTSP document 1 which is the master curriculum document or national curriculum . The school will arrange the curriculum that will be used and then a workshop will be held to present the results of the curriculum preparation that is used to the service, supervisors and school committees. In determining the suitability of the curriculum used, schools have their own instruments to measure the suitability level of SBC used.

The implementation of the curriculum system at SDN Bareng 3 Malang there are no serious problems, but there are several obstacles. Which inhibitory aspects can come from students, teachers, and school infrastructure? If the students' problems are faced such as the difficulty of understanding learning based on the 2013 curriculum which requires students to master learning through thematic, the teacher has difficulty in delivering material, and the limited facilities and infrastructure used to support the learning process based on the curriculum used. However, these various problems only took place at the beginning of the use of the 2013 curriculum which is since 2014, after which the school was able to overcome these technical problems, because the curriculum had been developed according to the circumstances and needs of the school.
So basically, the curriculum system implemented in SD Negeri Bareng 3 Malang refers to components related to the objectives, content, process and evaluation. The preparation of the curriculum focuses on the goals of national education with the hope of producing superior and quality students. Components related to the content and process of curriculum development are regulated by the schools, in this case teachers and principals for later the education office, supervisors, until the school committee plays a role from the beginning of planning to revision. For later through the evaluation phase which is measured from the level of understanding of students in the implementation of learning. These parties are important aspects in the success of the school curriculum system. Every school program is held both related to the learning process and outside of learning for example extracurricular always refers to the curriculum with the aim that the implementation of school activities refers to the curriculum system as a whole as a whole.

\section{School Curriculum Components}

In general, in planning a curriculum one must consider the needs of the community, the characteristics of the learner, and the scope of knowledge. The curriculum component used in a school must be adapted to the needs of the school and must meet National education standards. Researchers conducted a curriculum component study at SD Negeri Bareng 3 in accordance with the distribution of curriculum components according to Glenys G. Unruh and Adolph Unruh (in Arifin, 2014: 80-81) regarding the development of curriculum components based on curriculum definitions, namely a plan about: (a) objectives; (b) the content of what is learned and contained therein; (c) the learning process; and (d) evaluation for learning outcomes. The curriculum component implemented at SD Negeri Bareng 3 includes several components such as; objective component, content component, process component, and evaluation component.

\section{Component of Purpose}

In compiling a curriculum, the formulation of objectives is determined first before determining the other components. We can see the full educational objectives in the 1975 to 1994 curriculum which are goal oriented, whereas in the 2004 Curriculum or the Competency Based Curriculum it is known as the Graduates Competency Standards. (SKL), Competency Standards (SK) subjects, Basic Competence (KD), and indicators. The difference is, if the goal must be achieved by students, while competence must be mastered by students.

Based on the theory of the objectives, the researcher identifies curriculum component components that exist in SD Negeri Bareng 3. The following are examples of curricular objective components applied at SD Negeri Bareng 3. Examples of objective components include; Core Competencies and Basic. Competencies applied at SD Negeri Bareng 3. The researcher took the example of core competencies and basic competencies one of the subject themes applied at SD Negeri 3 Bareng.

a. Core Competencies, are designed along with the increasing age of students in certain classes. Through core competencies, vertical integration of various basic competencies in different classes can 
be maintained. The following (Figure 1) is an example of a Learning Implementation Plan for one of the subject themes in SD Negeri Bareng 3.

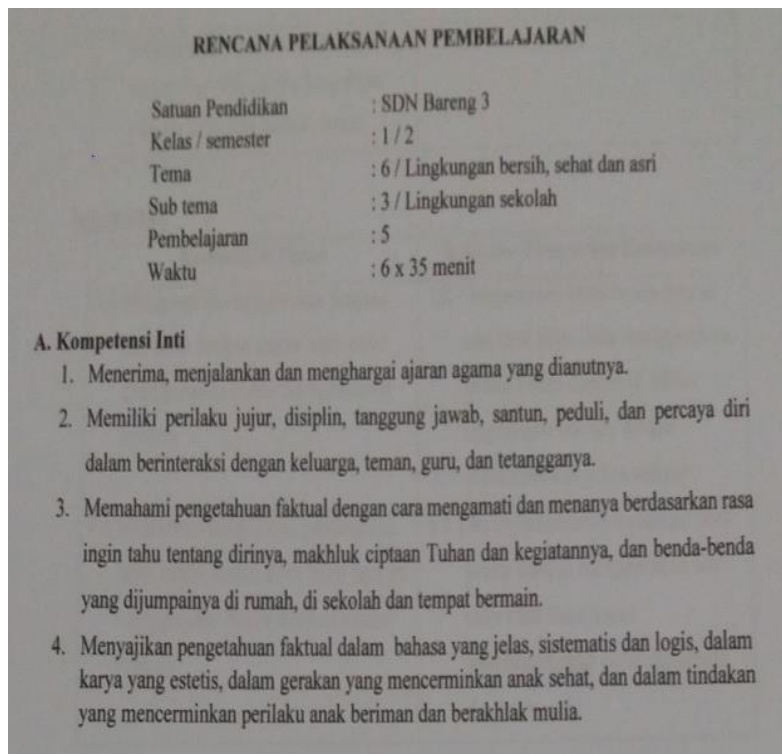

Figure 1

Learning Implementation Plan

From Figure 1 it can be seen that SD Negeri Bareng 3 has implemented a curriculum in accordance with existing theories. In the implementation of learning design that is implemented in SD Negeri Bareng 3 has included core competencies. Where core competencies are components of curriculum objectives.

b. Basic competencies, are formulated to achieve core competencies. The formulation of basic competencies is developed by paying attention to the characteristics of students, initial abilities and characteristics of a subject (Figure 2).

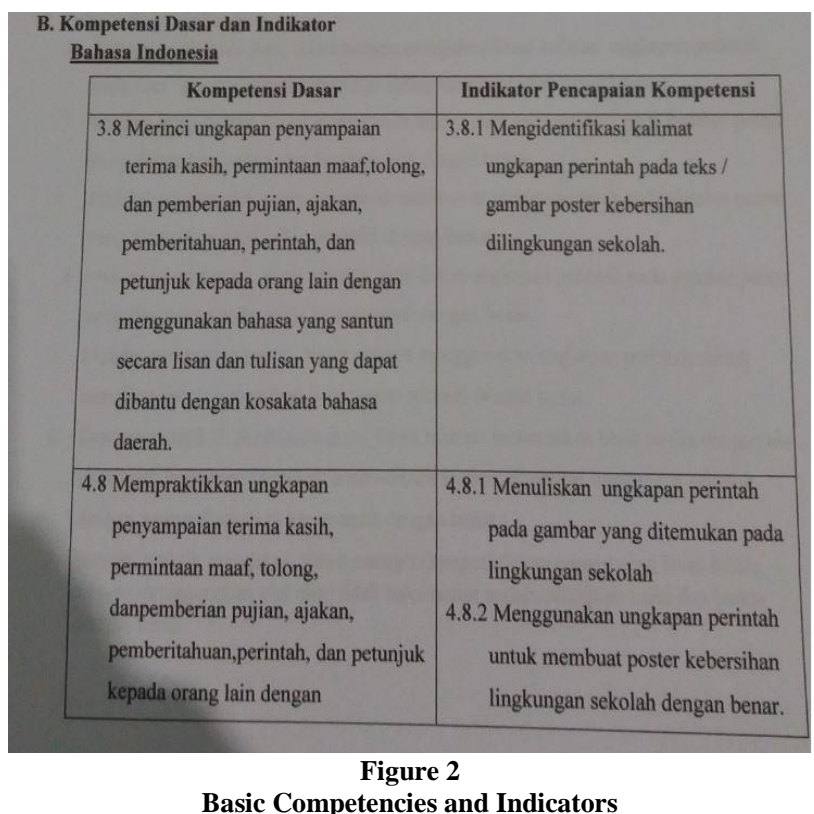

Figure 2 contains about Basic Competence a theme of lessons which is a component of the objectives in the preparation of the curriculum. It can be seen that the basic competencies applied to one of the subject themes have met existing standards, where the basic competencies are developed by taking into account the characteristics of students and displaying the characteristics of a subject. Figure 2 describes the basic competencies students must achieve on the theme of the lesson on a beautiful environment healthy, and clean as shown in Figure 1 as core competencies, it is seen if the development of basic competencies is in accordance with existing core competencies.

\section{Component Contents}

The contents of the curriculum are subjects in the teaching and learning process, such as knowledge, skills, and values associated with the subjects. Content selection emphasizes the approach of subjects (knowledge) or process approach (skills). In formal education curricula, in general the organization of contents / curriculum material is arranged in the form of subjects and / or fields of study contained in the curriculum structure in accordance with their respective institutional goals respectively. The structure also regulates the time allocation given to each subject or subject teach week.

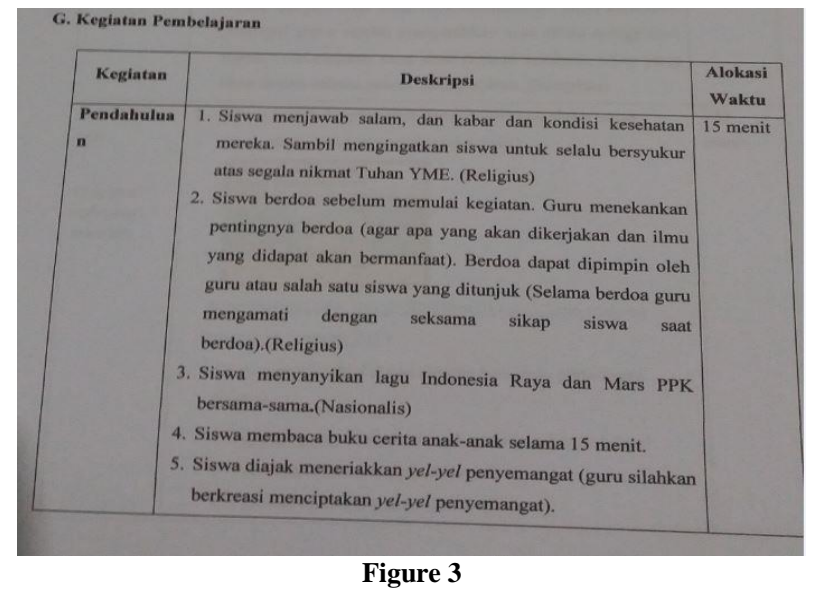

Learning Education

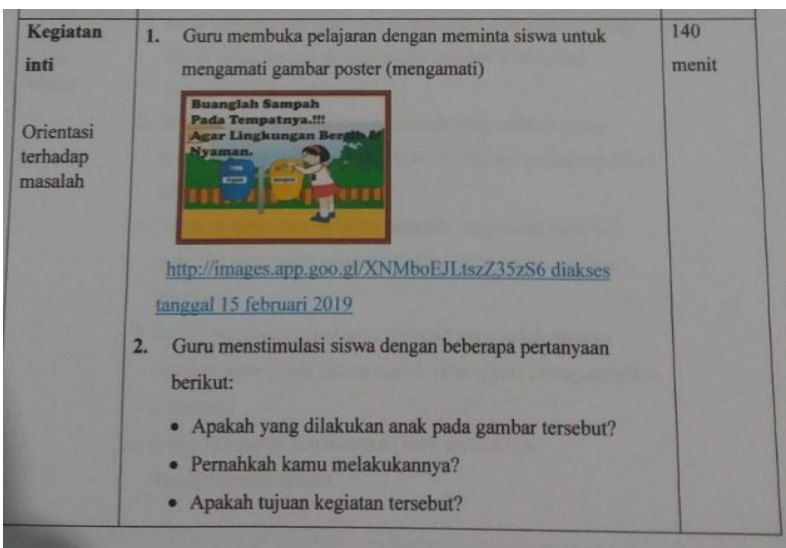

Figure 4

Leaning Process

Figures 3 and 4 show the elaboration of subjects in the form of learning activities, lesson descriptions, and time allocation. The elaboration of these subjects is included in the content component in the preparation of a curriculum. It appears that the elaboration of curriculum content conducted by SD Negeri Bareng 3 is correct 
because it includes learning activities, lesson descriptions, and time allocation given to each field of study for a week.

\section{Process Components}

The curriculum implementation process must demonstrate the existence of learning activities, namely the efforts of teachers to teach students, both at school through face-to-face activities, and outside of school through structured and independent activities. The selection of learning strategies must be adjusted to the curriculum objectives (SK / KD), the characteristics of the subject matter, and the level of development of students. The method is the way the teacher uses it to deliver curriculum content or subject matter in accordance with curriculum objectives. In learning activities, teachers must be able to use multimedia, both visual media, audio media, and audio-visual media. Visual media is media that can only see.

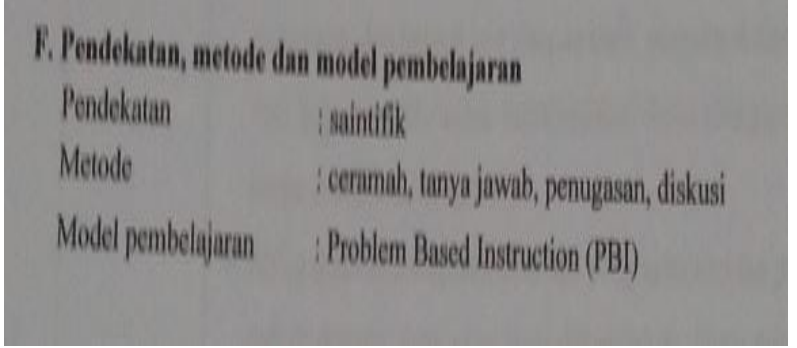

Figure 5

Learning Approaches, Methods and Models

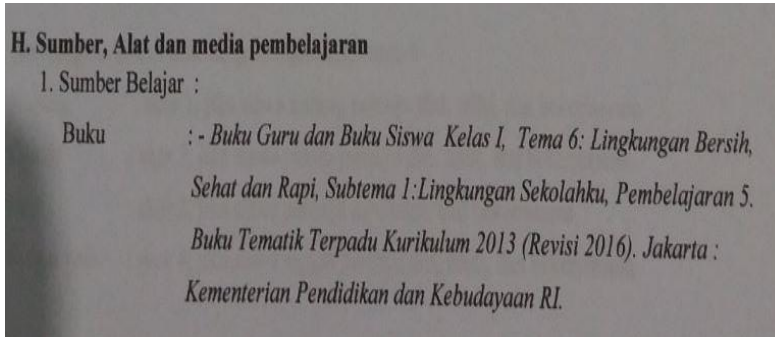

Figure 6

Learning Resources, Tools and Media

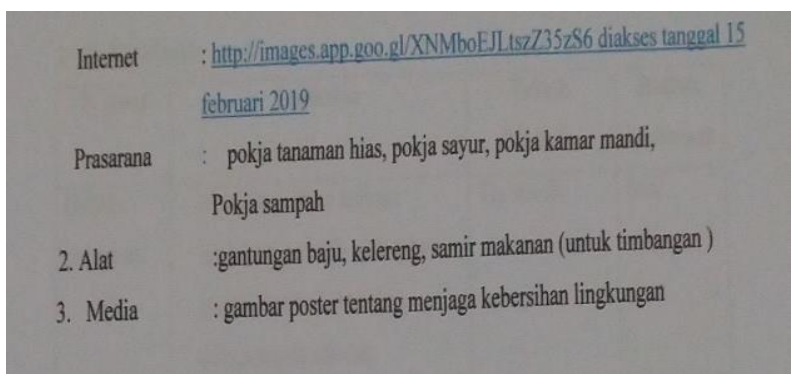

Figure 7

Resources, Tools, and Learning Media

From the three pictures above (Figure 5; Figure 6; Figure 7), it can be seen that SD Negeri Bareng 3 has used the right curriculum component. From Figure 5 the learning process has been described using the approaches, methods and learning models used during the learning activities. From Figure 6 and Figure 7 also seen sources, tools, and learning media that are used to support learning activities and processes in order to run well. In learning activities teachers are required to use learning resources, tools, and media that are interesting and innovative so that the learning process runs smoothly and produces good output for students.

\section{Evaluation Component}

Based on the definition of the curriculum used will be known what aspects will be evaluated. To find out aspects of curriculum evaluation, it can be seen from the perspective of the curriculum evaluation model. Curriculum evaluation is needed to determine the effectiveness of the curriculum and to improve and refine a curriculum.

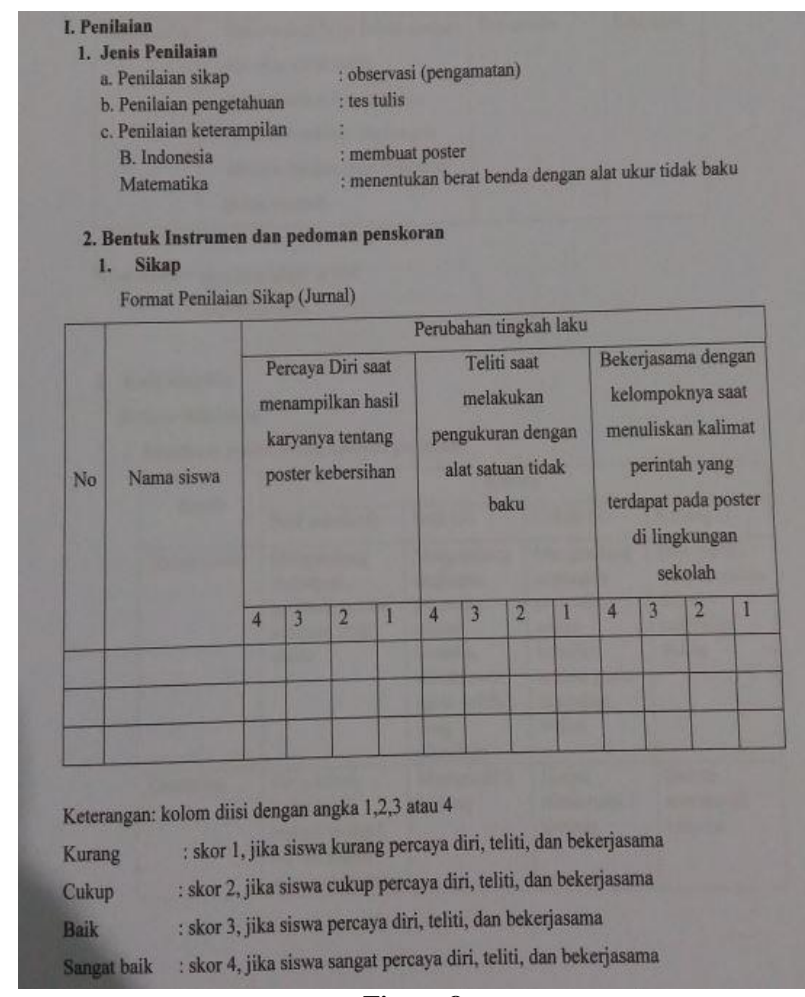

Figure 8

Ratings, Instrument Forms and Scoring Guidelines

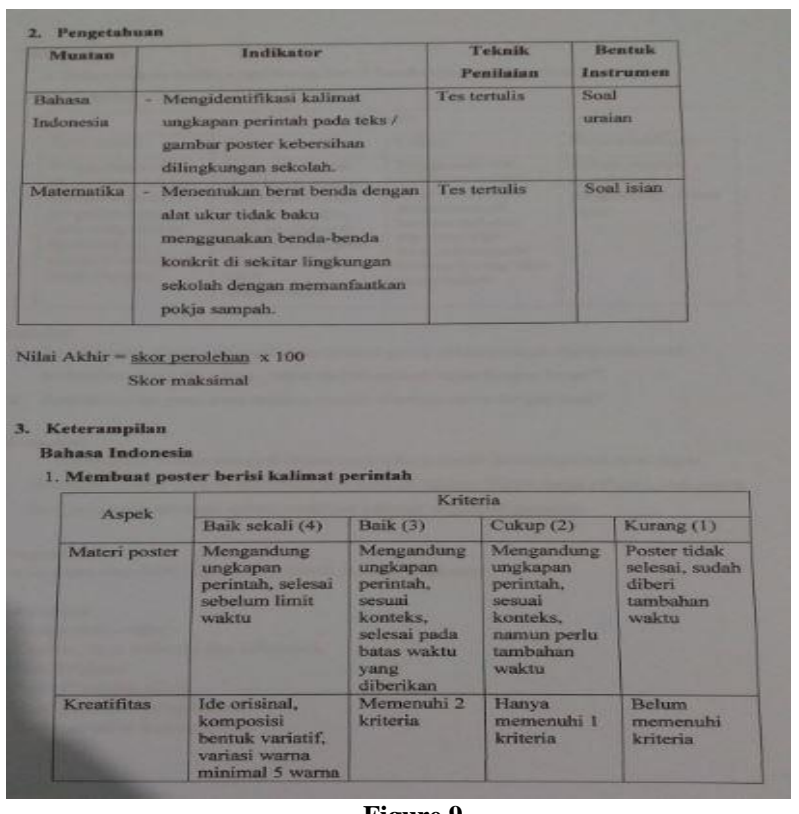

Figure 9

Knowledge and Skills Assessment 
From the two pictures (Figure 8; Figure 9), it can be seen that the evaluation instruments applied by the SD Negeri Bareng 3 are in accordance with existing theories. Figures 4.8 and 4.9 show how schools evaluate student learning outcomes in one of the subjects at school. Schools assess several aspects such as attitudes, knowledge, and skills to determine the level of student success in mastering a subject. This evaluation needs to be done to determine the effectiveness of a curriculum so that improvements and improvements can be made to achieve better result.

\section{The Influence of the Curriculum as a System of Curriculum Renewal}

Based on existing theories and findings in the field, the influence of the curriculum as a system outlines how each component in the curriculum is integrated into one unit to form input in this case learners. Prepare initial objectives that will be generated later, then how students go through the learning process, measuring the extent of the level of understanding and achievement of the learning process. each use of the curriculum measures the level of needs and circumstances of students, so that it can be adjusted and then developed so that the implementation of learning can run in accordance with the expected goals (Figure 10).

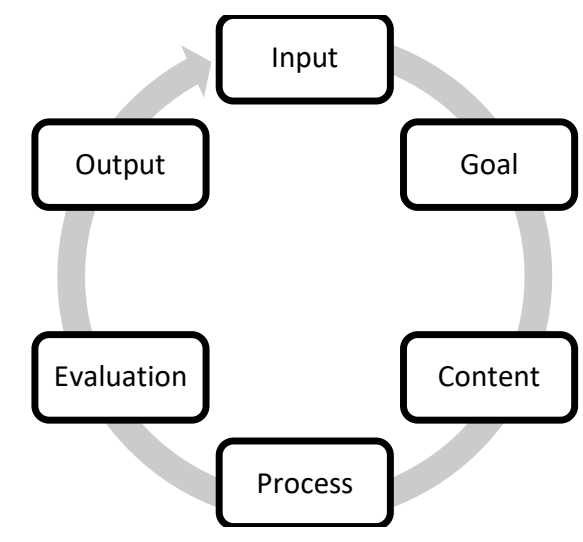

Figure 10

The Influence of the Curriculum as a System of Curriculum Renewal

In SDNegeri 3 together the influence of the curriculum as a system for example at the beginning of the use of KTSP 2013 there were many problems related to teachers, students and infrastructure in schools. Because the adjustment from KTSP 2006 to 2013 is considered to be a boomerang for teachers and students. students find it difficult to accept curriculum-based learning in 2013, it is an obstacle to the implementation of the learning process because it requires more time for teachers to explain. From these problems the school then identifies the needs of students so that the curriculum used can be developed and create new colors in schools such as the existence of adiwiyata, PPK, and 21 st century skills, in which these activities are adjusted to the parent curriculum only only undergoing an update by the school has been approved by the head of office, supervisor, and school committee.

\section{CONCLUSION}

The implementation of the curriculum as a system is an overall part of the various curriculum components that form a single unit in carrying out the teaching and learning process. The curriculum as a system that takes place in SDNegeri Bareng 3 Malang starts from the beginning of curriculum planning in which many parties take part in the preparation of this curriculum. These parties are teachers, principals, heads of offices, supervisors and school committees.

The curriculum used by schools is the result of updating the (national) master curriculum and then adjusting the situation of the school to then be used as a syllabus to become RPP. Overall academic and nonacademic school activities have been adapted to the curriculum used, so that the system that runs in carrying out the existing components can run according to established educational goals. In this case the influence of the system on curriculum renewal is related to the extent to which school achievement develops the curriculum in accordance with the needs and circumstances of the school in the implementation of the learning process.

\section{REFERENCES}

[1] Abdullah. (2011). Pengembangan Kurikulum Teori dan Praktek. Yogyakarta: Ar Ruzz Media.

[2] Andrian, D., Kartowagiran, B., \& Hadi, S. (2018). The Instrument Development to Evaluate Local Curriculum in Indonesia. International Journal of Instruction, 922

[3] Arifin. (2014). Konsep Model Pengembangan Kurikulum. Bandung: PT Remaja Rosdakarya.

[4] Cooper, T. (2017). Curriculum Renewal: Barriers to Successful Curriculum Change and. Journal of Education and Training Studies, 116.

[5] Hamalik, O. (2013). Dasar - Dasar Pengembangan Kurikulum. Bandung: PT Remaja Rosdakarya.

[6] Nhlapo, M. D., \& Muharajh, L. R. (2017). Engaging Foreign Curriculum Experts in Curriculum Design: A Case Study of Primary School Curriculum Change in Lesotho. Universal Journal of Educational Research, 1741.

[7] Rumahlatau, D., Huliselan, E. K., \& Takaria, J. (2016). An Analysis of the Readiness and Implementation of 2013 Curriculum in The West Part of Seram District, Maluku Province, Indonesia. International Journal of Environmental \& Science Education, 5663.

[8] Ryeo, P. J., Emzir, \& Kora, S. (2018). Curriculum Model for Indonesian Major at Busan University of Foreign Studies. Advances in Language and Literary Studies, 151.

[9] Suparlan. (2011). Tanya Jawab Pengembangan Kurikulum dan Materi Pembelajaran. Jakarta: PT Bumi Aksara.

[10] Wahyudin. (2014). Manajemen Kurikulum. Bandung: PT Remaja Rosdakarya. 